\title{
Solid Contact Potentiometric Sensors Based on Host-Tailored Molecularly Imprinted Polymers for Creatine Assessment
}

\author{
Ayman H. Kamel ${ }^{1, *}$, Abeer M. E. Hassan ${ }^{2}$ \\ ${ }^{1}$ Department of Chemistry, Faculty of Science, Ain Shams University, Cairo, Egypt, \\ ${ }^{2}$ Analytical Chemistry Department, Faculty of Pharmacy, October 6 University, Giza, Egypt \\ *E-mail: ahkamel76@sci.asu.edu.eg
}

doi: $10.20964 / 2016.11 .40$

Received: 3 June2016 / Accepted: 6 September 2016 / Published: 10 October 2016

\begin{abstract}
Potentiometric sensors for organic ions are in principle suitable for quick in situ determinations. A basic point in the improvement of these sensors is to discover particular receptors. In this examination, the probability of developing solid state potentiometric sensors with molecularly stamped polymers (MIP) as a recognition element was researched. Preparation of molecular imprinting polymers (MIP) as synthetic receptors for creatine and implemented in potentiometric sensors based on theepoxygraphite matrix as a conductive solid contact. These MIPs are depending on the utilization of methacrylic acid (MAA) and 2-vinyl pyridine (2-VP) as utilitarian monomers. Sensors based on (MAA) and (2-VP) exhibited a stable response over a linear range $9.0 \times 10^{-6}-10^{-2}$ and $1.0 \times 10^{-5}-10^{-2} \mathrm{~mol}$ $\mathrm{L}^{-1}$ creatinecation with slopes of $57.1 \pm 0.2$ and $54.1 \pm 1.2 \mathrm{mV}$ decade $\mathrm{e}^{-1}$ and detection limits of $7.0 \times 10^{-6}$ and $6.0 \times 10^{-6} \mathrm{~mol} \mathrm{~L}^{-1}$ in $10^{-2} \mathrm{~mol} \mathrm{~L}^{-1}$ citrate buffer solution has $\mathrm{pH} \mathrm{3}$, respectively. It was worth noting that the developed membrane sensors exhibited good selectivity towards creatine over many organic and inorganic cations, as well as some additives encountered in the pharmaceutical preparations and so these sensors, were successfully used for determination of creatine. The createdsensors were also utilized effectively for the quantification of creatine in serum as biological fluids. The resultsobtained were in great concurrencewith the information got by the measure spectrophotometry.
\end{abstract}

Keywords: Creatine, Molecularly imprintedpolymers, potentiometric sensors

\section{FULL TEXT}

(C) 2016 The Authors.Published by ESG (www.electrochemsci.org). This article is an open-access article distributed under the terms and conditions of the Creative Commons Attribution license (http://creativecommons.org/licenses/by/4.0/). 